\title{
PENGEMBANGAN LEMBAR KERJA PESERTA DIDIK (LKPD) BERBASIS INKUIRI TERBIMBING MATERI SISTEM ORGANISASI KEHIDUPAN
}

\author{
Yosefina Selmin ${ }^{1 *}$, Yohanes Nong Bunga ${ }^{2}$, Yohanes Bare $^{3}$ \\ ${ }^{123}$ Universitas Nusa Nipa Indonesia, Maumere, 86181, Indonesia \\ *e-mail: selminyosefina10@gmail.com
}

\begin{abstract}
Abstrak
Berdasarkan hasil observasi yang dilakukan di kelas VII SMP Negeri 1 Kewapante diperoleh bahwa peserta didik kurang terlibat aktif dalam pembelajaran biologi, media dan metode pembelajaran masih terbatas. Berdasarkan permasalahan tersebut, salah satu upaya yang dilakukan adalah dengan mengembangkan LKPD. Penelitian ini dilaksanakan dengan tujuan untuk : (1) Mengembangkan dan menganalisis tahap pengembangan LKPD berbasis InkuiriTerbimbing pada materi sistem organisasi kehidupan, (2) Menganalisis kelayakan LKPD berbasis inkuiri terbimbing pada materi sistem organisasi kehidupan yang dikembangkan. Jenis penelitian ini adalah penelitian pengembangan yang mengadopsi model pengembangan ADDIE. Produk LKPD divalidasi oleh ahli materi, media dan bahasa. Hasil validasi materi di peroleh nilai persentase $84 \%$ dengan kategori sangat valid, hasil validasi media diperoleh nilai persentase $90 \%$ dengan kategori sangat valid, dan hasil validasi bahasa diperoleh nilai persentase $90 \%$ dengan kategori sangat valid. Berdasarkan hasil penelitian disimpulkan bahwa pengembangan lembar kerja peserta didik (LKPD) pada materi sistem organisasi kehidupan untuk kelas VII SMP telah layak digunakan dalam proses pembelajaran.
\end{abstract}

Kata Kunci: LKPD, Inkuiri Terbimbing, Sistem Organisasi Kehidupan

DOI: http://dx.doi.org/10.55241/spibio.v3i1.52 


\section{Pendahuluan}

Pendidikan merupakan sarana yang berperan untuk menciptakan manusia yang berkualitas. Pendidikan mendorong manusia berusaha mengembangkan diri sehingga mampu menghadapi setiap perubahan yang terjadi akibat adanya kemajuan ilmu pengetahuan. Tujuan Pendidikan Nasional menurut UU No. 20 Tahun 2003 pasal 3, untuk berkembangnya potensi peserta didik agar menjadi manusia yang beriman dan bertakwa kepada Tuhan Yang Maha Esa, berakhlak mulia, sehat, berilmu, cukup, kreatif, mandiri dan menjadi warga Negara yang demokratis serta bertanggung jawab (Khasanah 2020)

Kurikulum yang diterapkan hanya beberapa pendidikan saat ini, yaitu kurikulum 2013. Kurikulum 2013 merupakan kurikulum yang mengacu pada pembentukan sikap peserta didik, pengetahuan dan ketrampilan, pembelajaran yang digunakan sesuai kurikulum ini juga hendaknya dilaksanakan secara kreatif. Pembelajaran biologi diharapkan memungkinkan terbentuknya integrasi antara pembekalan kognitif, pembentukan sikap dan ketrampilan peserta didik. Pada kurikulum 2013, dalam permendikbud No 24 tahun 2014 tentang kompetensi inti (KI) dan kompetensi dasar (KD) telah disiapkan untuk guru dalam mengembangkan perangkat pembelajaran. Selanjutnya guru dapat mengembangkan kedalam indikator pencapaian berdasarkan tahapan dalam taksonomi Anderson (perbaikan taksonomi bloom) (Kemendikbud 2013).

Pembelajaran biologi merupakan pembelajaran yang menarik, menyenangkan, dan berkaitan dengan kehidupan sehari-hari. Peserta didik harus dapat memahami konsep-konsep materi yang diberikan guru pada saat proses pembelajaran, agar pembelajaran biologi dapat terlaksana dan tercapainya tujuan pebelajaran yang maksimal. Sarana untuk mencapai tujuan pembelajaran yang maksimal yaitu diperlukan suatu mediapembelajaran yang mampu menambah keinginan dan rasa ingin tahu peserta didik tentang suatu permasalahan (Kari, 2022; Kurniawan 2013; Ndia, 2021; S and Bare 2019).

Pembelajaran harus memberikan pengalaman belajar, melibatkan proses mental dan fisik melalui interaksi antar peserta didik dengan peserta didik, peserta didik dengan guru, peserta didik dengan lingkungan dan peserta didik dengan sumber belajar (Dawa, Bunga, and Bare 2021; Ra'o, Bare, and Putra 2021; Ule, Bunga, and Bare 2021). Didalam pembelajaran perlu adanya variasi sumber belajar, metode dan strategi dalam mengajar hal ini bertujuan untuk menumbuhkan semangat peserta didik, membantu peserta didik untuk belajar yang menyenangkan, mengurangi kebosanan dan kemalasan dalam belajar. Salah satu alternatif pembelajaran yang berorientasi pada keaktifan peserta didik adalah dengan menggunakan model pembelajaran inkuiri terbimbing (Bare and Sari 2021; Lia 2019). Pembelajaran inkuiri terbimbing adalah model pembelajaran yang dalam 
pelaksanaannya guru memberikan atau menyediakan petunjuk/bimbingan yang luas terhadap peserta didik dan memberikan petunjuk-petunjuk terhadap materi yang akan diajarkan kepada peserta didik seperlunya (Pada, Bare, and Putra 2021; Tangkas 2012). Lembar kerja peserta didik (LKPD) merupakan media yang dapat digunakan dalam pembelajaran di kelas. Kelebihan dari LKPD adalah memudahkan pelaksanaan pengajaran sesuai dengan metode dan materi yang akan diajarkan guru kepada peserta didik dan mengarah peserta didik dalam melakukan pembelajaran di kelas. LKPD di buat untuk memperlancar dalam proses pembelajaran. LKPD merupakan salah satu alat yang digunakan untuk mengarahkan peserta didik dalam belajar agar tidak keluar dari materi yang di pelajari (Ade, Bare, and Mago 2021; Elci, Bare, and Mago 2021; Maulidar 2019).

Berdasarkan hasil observasi yang dilakukan kepada guru IPA di kelas VII SMP Negeri 1 Kewapante dinyatakan bahwa peserta didik kurang terlibat aktif dalam pembelajaran biologi. Dikarenakan mereka lebih banyak memproleh pengetahuan yang masih berpusat pada guru, sehingga peserta didik cenderung pasif pada saat pembelajaran biologi. Hal ini membuat peserta didik sulit untuk mengembangkan kemampuan dan pada saat pembelajaran, peserta didik hanya menggunakan sumber belajar yang disiapkan sekolah sehingga peserta didik merasa jenuh dalam pembelajaran karena keterbatasan media pembelajaran dan metode pembelajaran. Metode pembelajaran yang sering digunakan berupa ceramah, tanya jawab, dan diskusi sehingga kemampuan peserta didik dalam menganalisis masalah dalam pembelajaran masih terbatas.

Menurut Marti dkk (2016), salah satu materi yang sulit dipahami oleh peserta didik dalam pembelajaran biologi adalah materi sistem organisasi kehidupan. Sistem organisasi kehidupan merupakan suatu perangkat elemen-elemen kehidupan dari struktur yang terkecil sampai yang terbesar berupa sel, jaringan, organ, sistem organ, dan organisme yang masingmasing mempunyai tugas dan fungsinya tersendiri untuk menumpang kehidupan. Elemenelemen tersebut saling berhubungan dan saling mendukung satu sama lain, jika elemen tidak berfungsi maka akan mempengaruhi fungsi elemen yang lain, sehingga membentuk suatu sistem. Secara umum, keseluruhan isi materi dari materi ini merupakan konsep-konsep yang sifatnya abstrak, oleh karena itu dalam penyajian materi ini tidak cukup hanya disajikan dalam bentuk ceramah dan hafalan tetapi diperlukan suatu media untuk membantu sifat memahami materi tersebut.

Pengembangan LKPD berbasis inkuiri terbimbing telah di uji dalam suatu penelitian pada mata pelajaran matematika. Penelitian Fara, (2019), menunjukkan bahwa LKPD berbasis inkuiri terbimbing dapat meningkatkan kemampuan komunikasi matematis peserta didik. Hal ini dapat dilihat dari kemampuan komunikasi peserta didik yang menggunakan LKPD berbasis inkuiri terbimbing lebih tinggi dari pada kemampuan komunikasi peserta 
didik yang mengikuti pembelajaran dengan LKPD biasa. Pengembangan LKPD berbasis inkuiri terbimbing menghasilkan LKPD yang lebih efektif dibandingkan dengan LKPD biasa. Hal ini dapat dilihat dari permasalahan yang diberikan berasal dari lingkungan sekitar dan bersifat konstruktivis dengan memperhatikan karakteristik yang dimiliki oleh pendekatan kontekstual. Setiap tahapan pada LKPD berbasis inkuiri terbimbing selalu memfasilitasi indikatorindikator kemampuan komunikasi matematis dan self efficacy siswa.

Penelitian Triana, (2018), tentang Pengembangan LKPD bebasis inkuiri terbimbing materi koligatif larutan di SMA Negeri 1 Mesjid Raya, meyatakan Pembelajaran dengan menggunakan LKPD berbasis inkuiri padamateri sifat koligatif larutan menunjukkan respon yang positif dari peserta

\section{Metode}

Penelitian yang digunakan adalah metode penelitian pengembangan (R\&D). penelitian pengembangan adalah suatu proses atau langkahlangkah untuk mengembangkan suatu produk yang baru atau menyempurnakan produk yang telah ada. Penelitian ini mengadopsi model Analysis, Design, Development, Implementation, Evaluation

\section{Hasil dan Pembahasan}

Hasil penelitian pengembangan LKPD berbasis inkuiri terbimbing, berdasarkan metode penelitian yang didik. Persentase respon peserta didik yang diperoleh adalah $76,25 \%$ sangat baik dan 23,75\%peserta didik baik terhadap LKPD berbasis inkuiri yang telah dikembangkan. Sementara itu, penelitian Ekawati (2017), tentang pengembangan LKPD berbasis inkuiri terbimbing untuk meningkatkan kemampuan representasi matematis dan self efficacy peserta didik. menyatakan bahwa kemampuan representasi matematis peserta didik yang menggunakan LKPD berbasis inkuiri terbimbing lebih tinggi daripada kemampuan representasi matematis peserta didikyang tidak menggunakan LKPD berbasis inkuiri terbimbing. Selain itu, peningkatan kemampuan representasi matematis peserta didik yang menggunakan LKPD berbasis inkuiri terbimbing dikategorikan tinggi. Sebagai sebuah solusi akademik, peneliti memandang perlu melakukan penelitian ini.

(ADDIE) yang telah di modifikasi dengan inkuiri terbimbing. Peneliti melakukan penelitian pada 30 Agustus 2021 sampai dengan 03 September 2021. Penelitian dilaksanakan di Sekolah Menengah Pertama (SMP) Negeri 1 Kewapante. Uji coba lapangan dilakukan untuk mengetahui kemenarikan, kemanfaatan, kemudahan, dan keefektifan LKPD.

dilakukan adalah sebagai berikut:

1. Tahap analisis (analysis) 
a. Analisis kebutuhan peserta didik Tahap ini bertujuan mencari solusi untuk permasalahan proses pembelajaran biologi di SMP Negeri 1 Kewapante. Guru SMP Negeri 1 Kewapante menyatakan bahwa peserta didik kelas VII kurang terlibat aktif dalam pembelajaran biologi kurangnya media pembelajaran atau bahan ajar. Hal ini sulit peserta didik untuk mengembangkan kemampuan dalam kelas. Untuk itu perlunya dilakukan pengembangan LKPD berbasis inkuiri terbimbing sebagai media pembelajaran serta guna membantu peserta didik dalam proses pembelajaran.

b. Analisis Kurikulum.

Pada tahap analisis kurikulum, peneliti melakukan analisis berbagai perangkat kurikulum yang berlaku. Analisis ini bertujuan untuk merumuskan indikator dan tujuan
pembelajaran berdasarkan
Kompetensi Inti (KI) dan Kompetensi Dasar (KD) yang berlaku di SMP Negeri 1 Kewapante. Berdasarkan penelitian kurikulum yang digunakan di SMP Negeri 1 Kewapante adalah kurikulum 2013. Sehingga seluruh perangkat kurikulum mengacu pada kurikulum 2013.

2. Desain (Design)

a. Perancangan desain produk

Langkah-langkah penyusunan desain produk LKPD ini, diantaranya adalah menyesuaikan standar komptensi dan kompetensi dasar berdasarkan kurikulum 2013. Desain produk pengembangan LKPD adalah terdiri dari:

1. Sampul/cover depan LKPD Cover merupakan halaman depan dari sebuah LKPD yang terdiri atas judul LKPD dan gambar ilustrasi materi dalam LKPD.

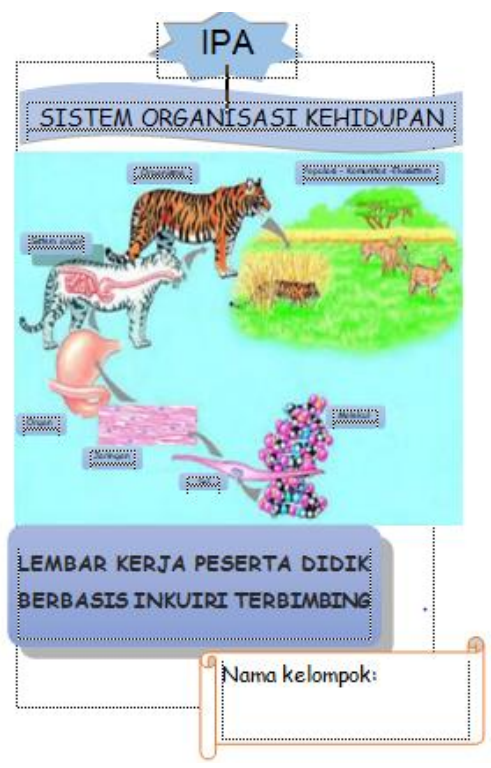


Gambar 1. Tampilan cover

2. Kata Pengantar Kata pengantar mengulas tentang gambaran singkat

tentang LKPD berbasis inkuiri terbimbing (Gambar 2).

KATA PENGANTAR

Puji syukur kepada Tuhan Yang Maha Esa atos perkenoanNya sehingga penulis menyelesaikan Lembar Kerja Peserta Didik (LKPD) Berbasis Inkuiri Terbimbing ni. LKPD ini juga membantu peserta didik untuk memahami materi di sekolah. LKPD berbasis inkuiri terbimbing ini berisi materi sitem organisasi kehidupan yaitu mulai dari sel, jaringan, organ, dan sistem organ. LKPD berbasis Inkuiri terbimbing ini, bertujuan untuk membantu siswa agar mampu memecahkar masalahry sendiri dan tidak menemukan konsep. Dimana pembelajaran ini tidak berpusat pada guru tetapi berpusat pada siswa. Oleh sebab itu, dalam proses pembelajaran guru harus bisa mengkontruksikan pemahaman siswa ogar konsep mudah diterima oleh siswa dan mampu menigkatkan kreatifitas, sikap ilmiah serta mengembangkan kemampuan berpikir untuk memecahkan masalah.

Penulis menyadari bahwa baryak kekurangan dalam penulisan LKPD ini Oleh karena itu, penulis sangat mengharapkan kritik dan saran yang membangur demi perbaikan LKPD ini. Penulis berharap ogar LKPD ini bermanfoat bogi peserte didik dalam menoapai cita-cita. Penulis juga mengucapkan teri akasih kepade semua pihak yang teah membantu dalam proses pembuatan LKPD.

Gambar 2. Tampilan Kata Pengantar (LKPD)

3. Daftar Isi

Bagian ini menginfornasikan kepada pengguna tentang topik-topik yang akan ditampilkan dalam LKPD berbasis inkuiri terbimbing sesuai urutan dan nomor halaman yang terdiri atas cover, kata pengantar, daftar isi, kompetensi inti, kompetensi dasar, indikator dan tujuan pembelajaran, peta konsep, kegiatan inkuiri terbimbing 1 , inkuiri terbimbing 2 , inkuiri terbimbing 3 , daftar pustaka.

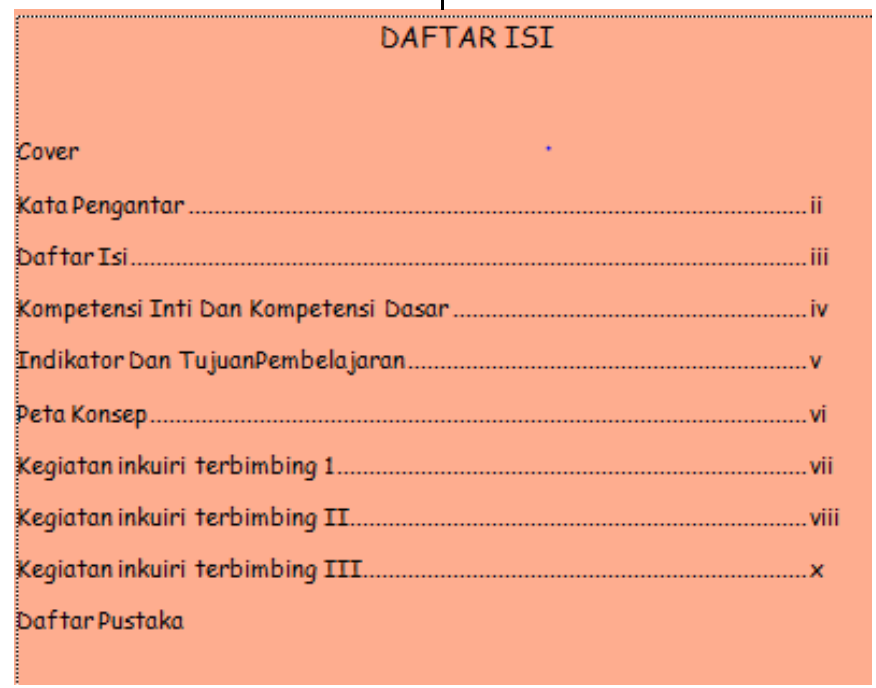


Gambar 3. Tampilan Daftar Isi (LKPD)

4. Kompetensi Inti (KI)

Kompetensi inti diturunkan dari

rumusan kurikulum 2013.

Terdapat dua kompetensi inti yang diperoleh yaitu (Gambar 4):

KOMPETENSI INTI

KI 3: Memahami, menerapkan, menganalisis dan mengevaluasi pengetahuan faktual, konseptual, prosedural, dan metakognitif berdasarkan rasa ingin Iahunya tentang ilmu pengetahuan, teknologi, seni, budaya dan humaniora dengan wawasan kemanusiaan, kebangsaan, kenegaraan, dan peradaban Ierkait penyebab fenomena dan kejadian, serta menerapkan pengetahuan prosedural pada bidang kajian yang spesifik sesuai dengan bakat dan minatnya untuk memecahkan masalah.

KI 4 : Mengolah, menalar, menyaji, dan mencipta dalam ranah konkret dan ranah abstrak terkait dengan pengembangan dari yang dipelajarinya di sekolah secara mandiri serta bertindak secara efektif dan kreatif, dan mampu monacuunakan motoda sasuai kaidah kailmouan

Gambar 4. Tampilan KI (LKPD)

5. Kompetensi Dasar (KD). Kompetensi dasar bertujuan untuk mencapai kompetensi inti yang harus diperoleh siswa melalui pembelajaran.

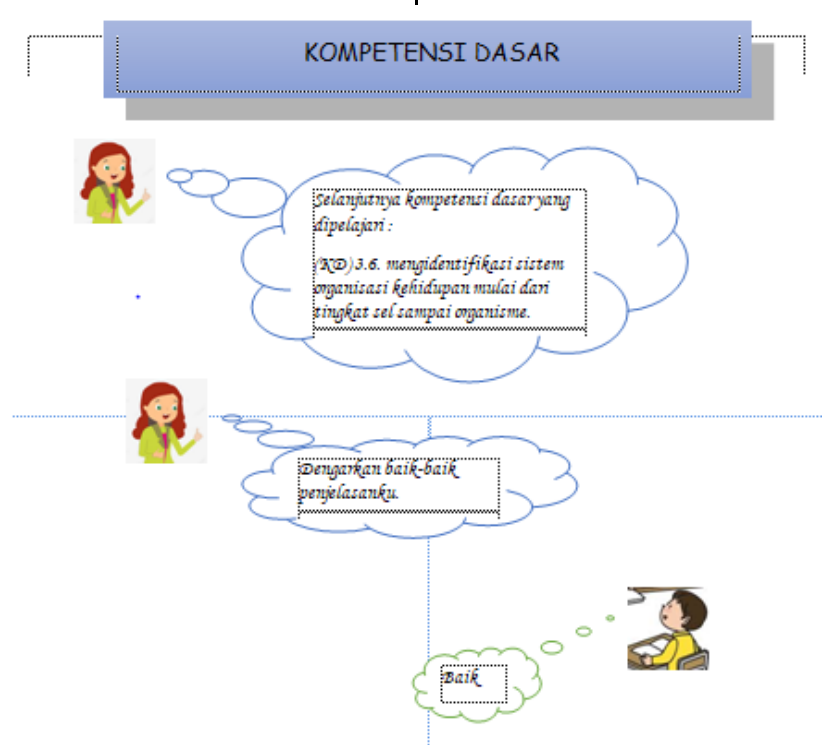

Gambar 5. Tampilan Kompetensi Dasar 
6. Indikator Pembelajaran

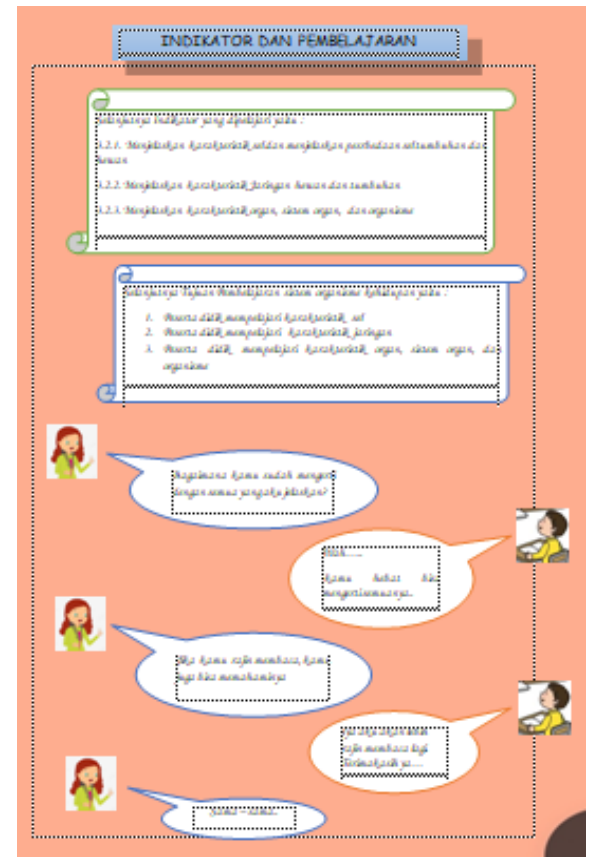

Gambar 6. Tampilan Indikator Pembelajaran

7. Peta Konsep

Peta konsep gambaran dari isi materi sistem organisasi kehidupan yang di rancang dalam media LKPD (Gambar 7).

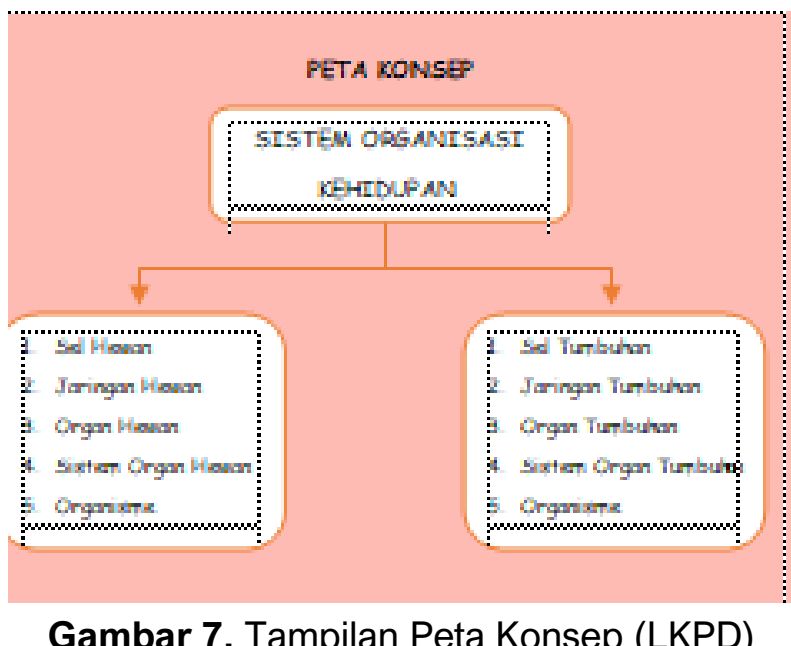

8. Kegiatan Inkuiri terbimbing 


Pada kegiatan inkuiri
terbimbing terdapat info-info
materi sistem organisasi
kehidupan yang harus peserta
didik pelajari. Kegiatan inkuiri

terbimbing ini dibagi menjadi 3 yaitu kegiatan inkuiri terbimbing I, kegiatan inkuiri terbimbing II dan kegiatan inkuiri terbimbing III.
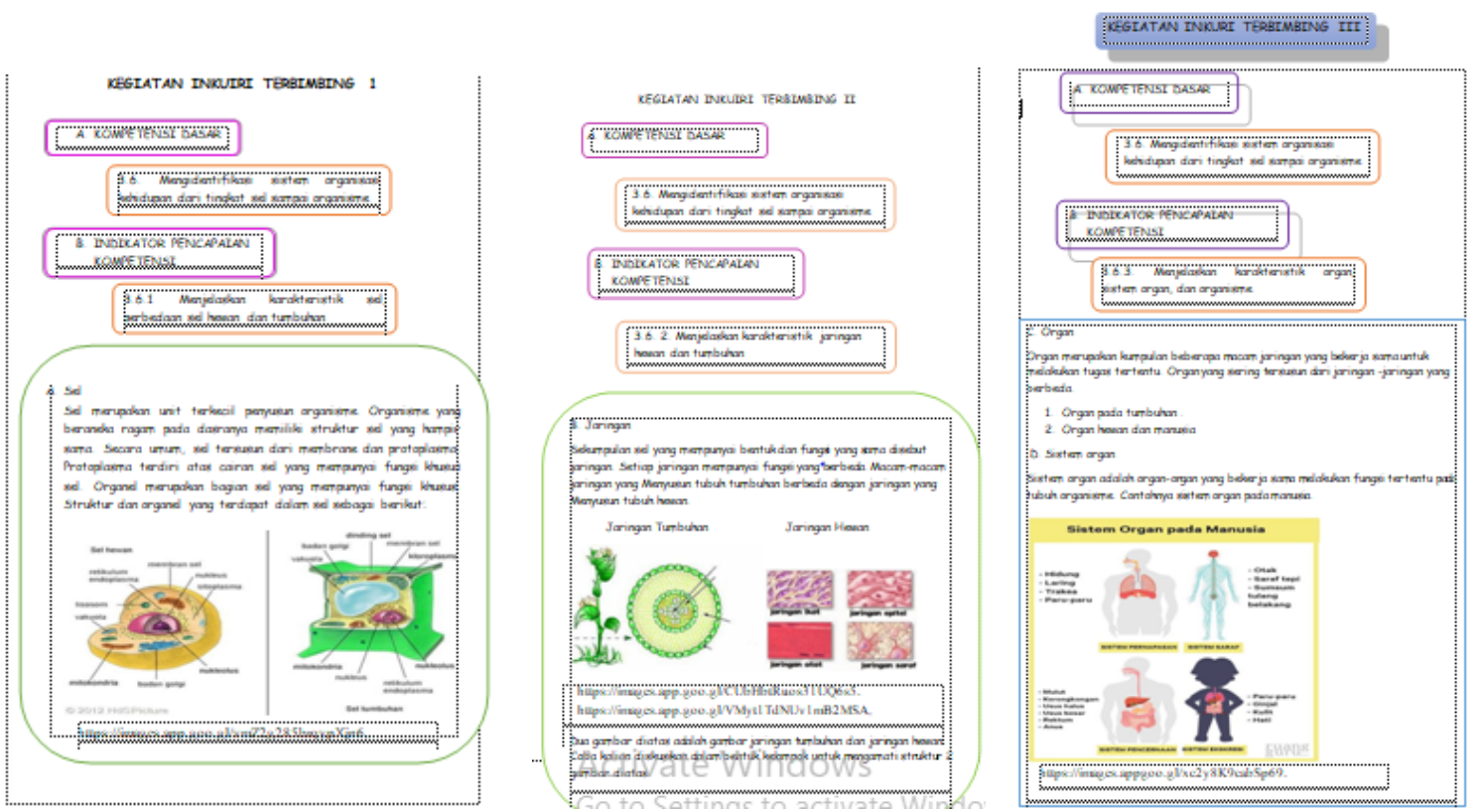

Gambar 8. Tampilan Kegiatan Inkuiri Terbimbing a) Kegiatan Inkuiri Terbimbing I, b) Kegiatan Inkuiri Terbimbing II, c) Kegiatan Inkuiri Terbimbing III

9. Penelusuran dan Diskusi

Memuat soal-soal yang akan di kerjakan untuk melatih kemampuan peserta didik terhadap materi sistem organisasi kehidupan di setiap pertemuan.
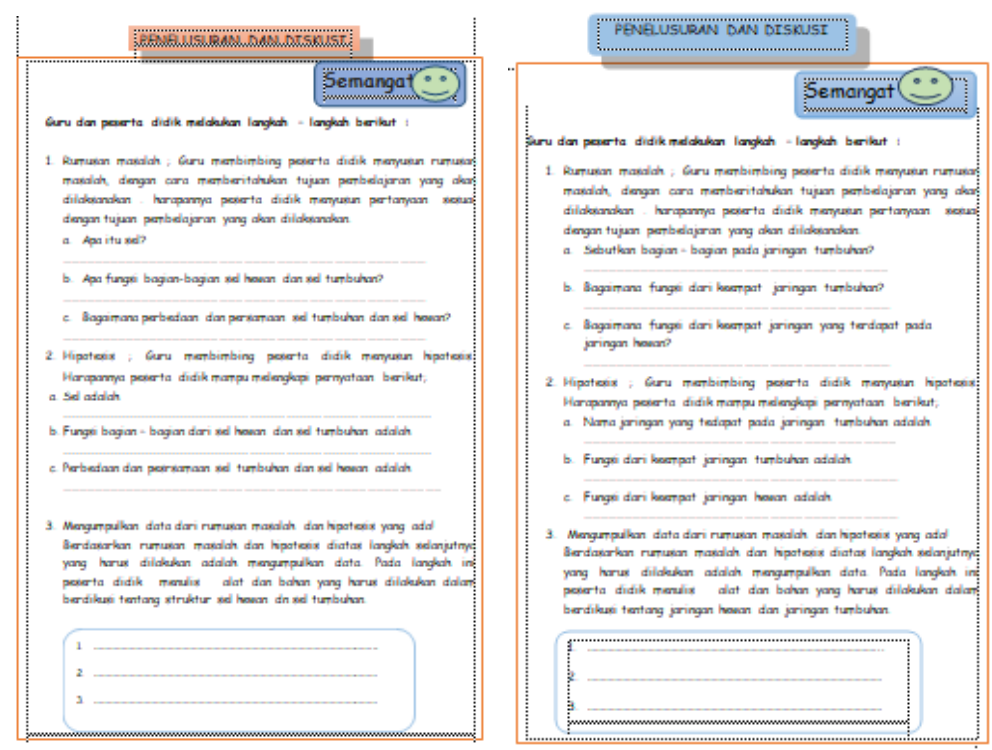

PENELUSURAN DAN DISKUSI
Guru dan peserta didik melakukan langkah - langkah berikut :
1. Rumusan masalah ; Guru membimbing peserta didik menyusun rumusan
masalah, dengan cara memberitahukan tujuan pembelajaran yang akar
dilaksanakan . harapannya peserta didik menyusun pertanyaan sesuaa
dengan tujuan pembelajaran yang akan dilaksanakan.
a. Organ-organ apa saja yang terdapat pada tumbuhan serta tuliskar
fungsinya masing-masing?
b. Organ apa saja yang terdapat pada hewan dan manusia serta tuliskan
fungsinya masing-masing?
2. Hipotesis ; Guru membimbing peserta didik menyusun hipotesis:
Harapannya peserta didik mampu melengkapi pernyataan berikut;
a. Organ-organ yang terdapat pada tumbuhan adalah


Gambar 9. Tampilan Penelusuran dan Diskusi

10. Komunikasikan

Dalam kegiatan

komunikasikan ini peserta

didik melaporkan hasil diskusi

masing-masing kelompok

melalui presentasi didepan kelas. Dengan adanya kegiatan ini peserta didik mampu berkomunikasi dalam menyampaikan pendapat.

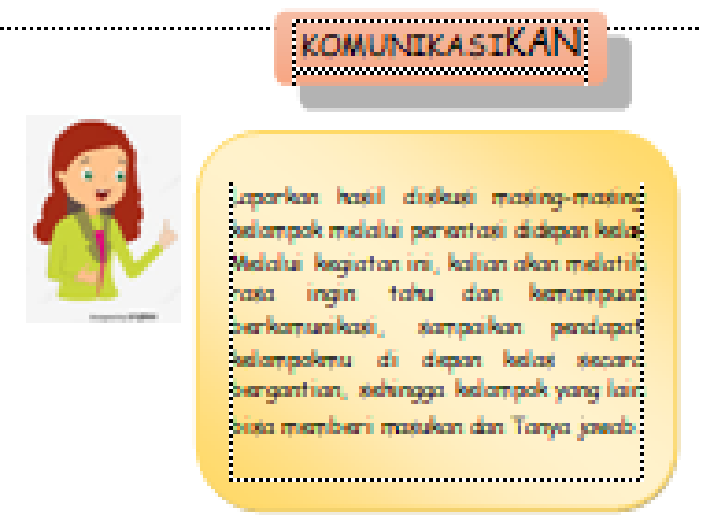

Gambar 10. Tampilan Komunikasikan

11. Kata Motivasi

Kata motivasi bertujuan untuk membangkitkan semangat

dan antusias peserta didik dalam belajar.

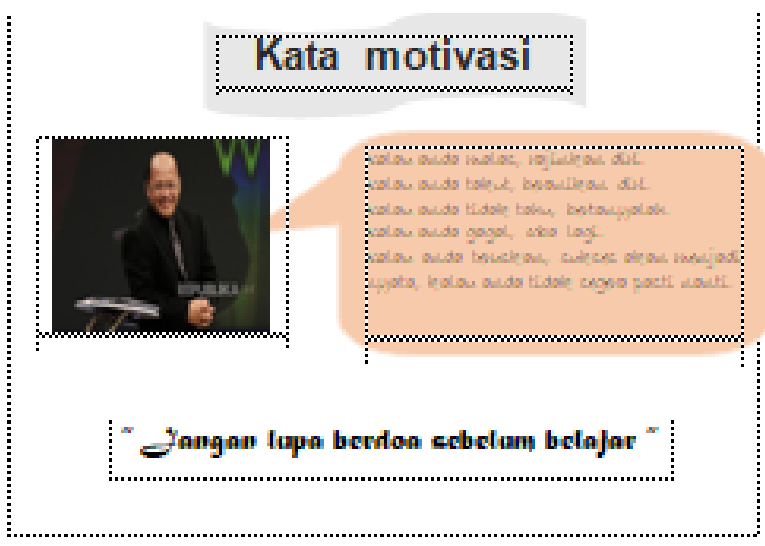

Gambar 11. Tampilan Kata Motivasi

12. Daftar Pustaka

Pada daftar pustaka memuat sejumlah reverensi yang digunakan sebagai bahan rujukan ditulis (Gambar 12). 


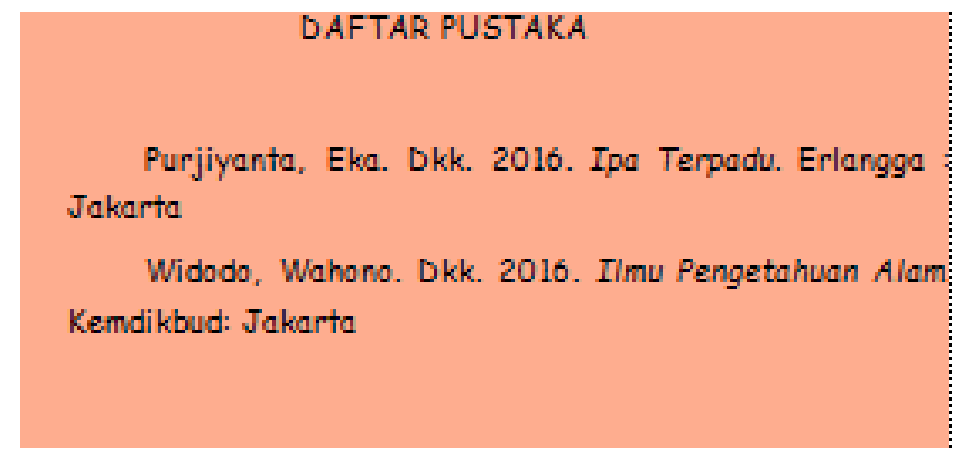

Gambar 12. Tampilan Daftar Pustaka

b. Pemilihan Media

Media yang digunakan adalah lembar kerja peserta didik (LKPD) berbasis inkuiri terbimbing pada materi sistem organisasi kehidupan.

c. Validasi media

Validasi materi
Validator materi melakukan validasi terhadap isi atau konten materi pada media pembelajaran yang dikembangkan. Jumlah pernyataan yang dinilai oleh validator materi sebanyak 10 pernyataan.

Tabel 1. Revisi dan hasil revisi berdasarkan ahli Materi

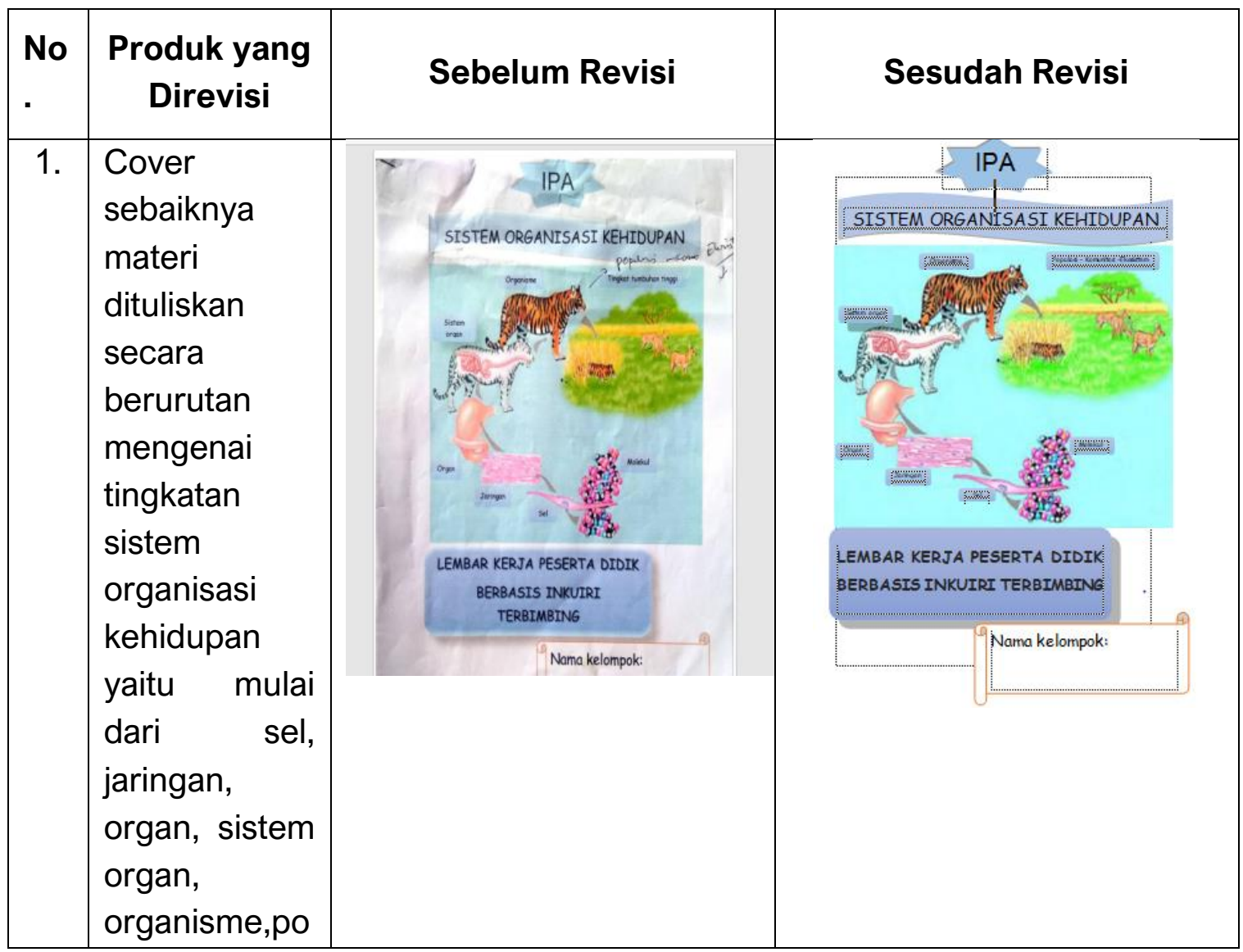




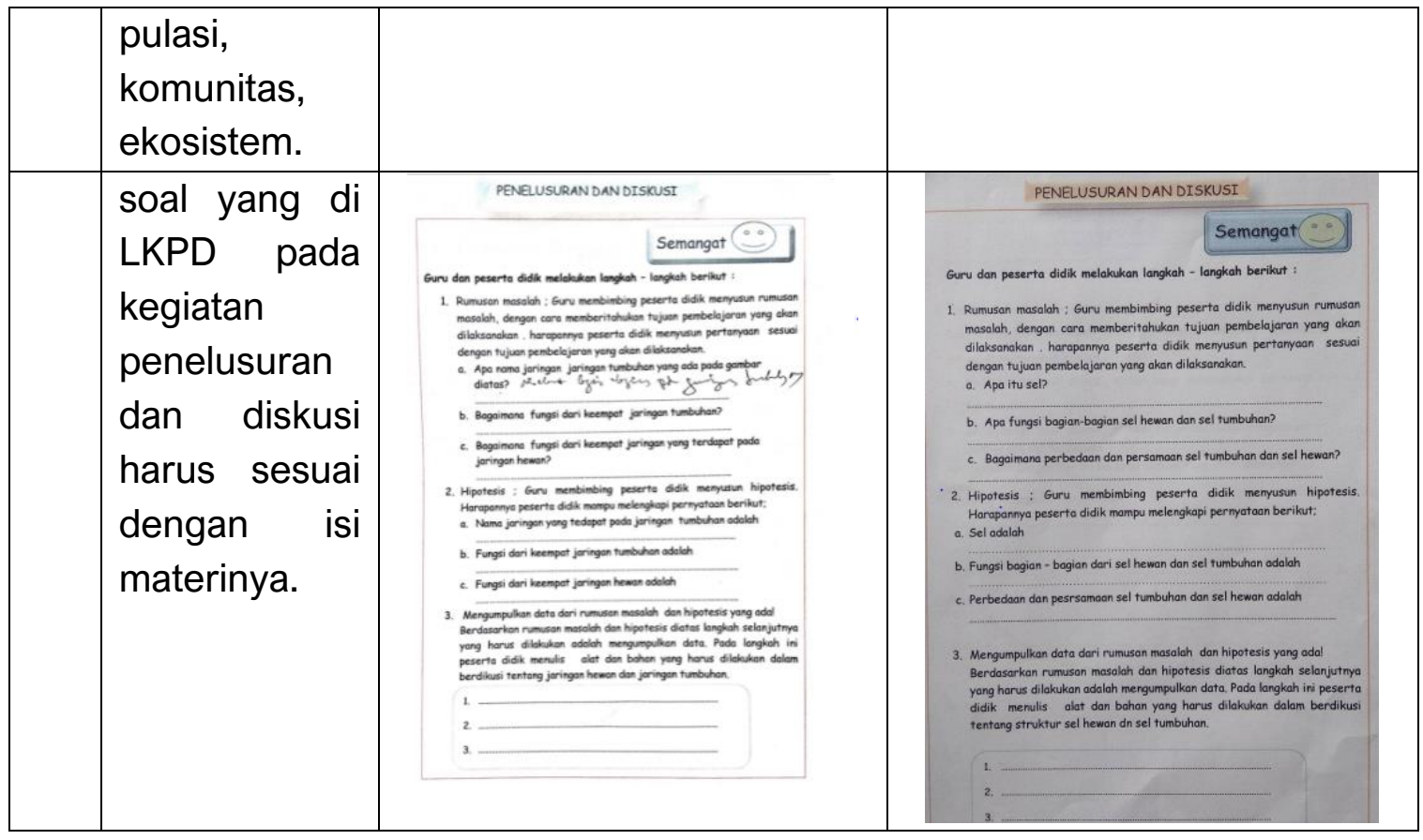

\section{Validasi media}

$\begin{array}{lr}\text { Validator media melakukan } \\ \text { validasi terhadap } r \text { media } \\ \text { pembelajaran } & \text { yang } \\ \text { dikembangkan dengan jumlah }\end{array}$

pernyataan sebanyak 10. Validasi yang dilakukan oleh validator materi mendapatkan beberapa saran perbaikan yaitu sebagai berikut:

Tabel 3. Revisi dan Hasil Revisi Ahli Media

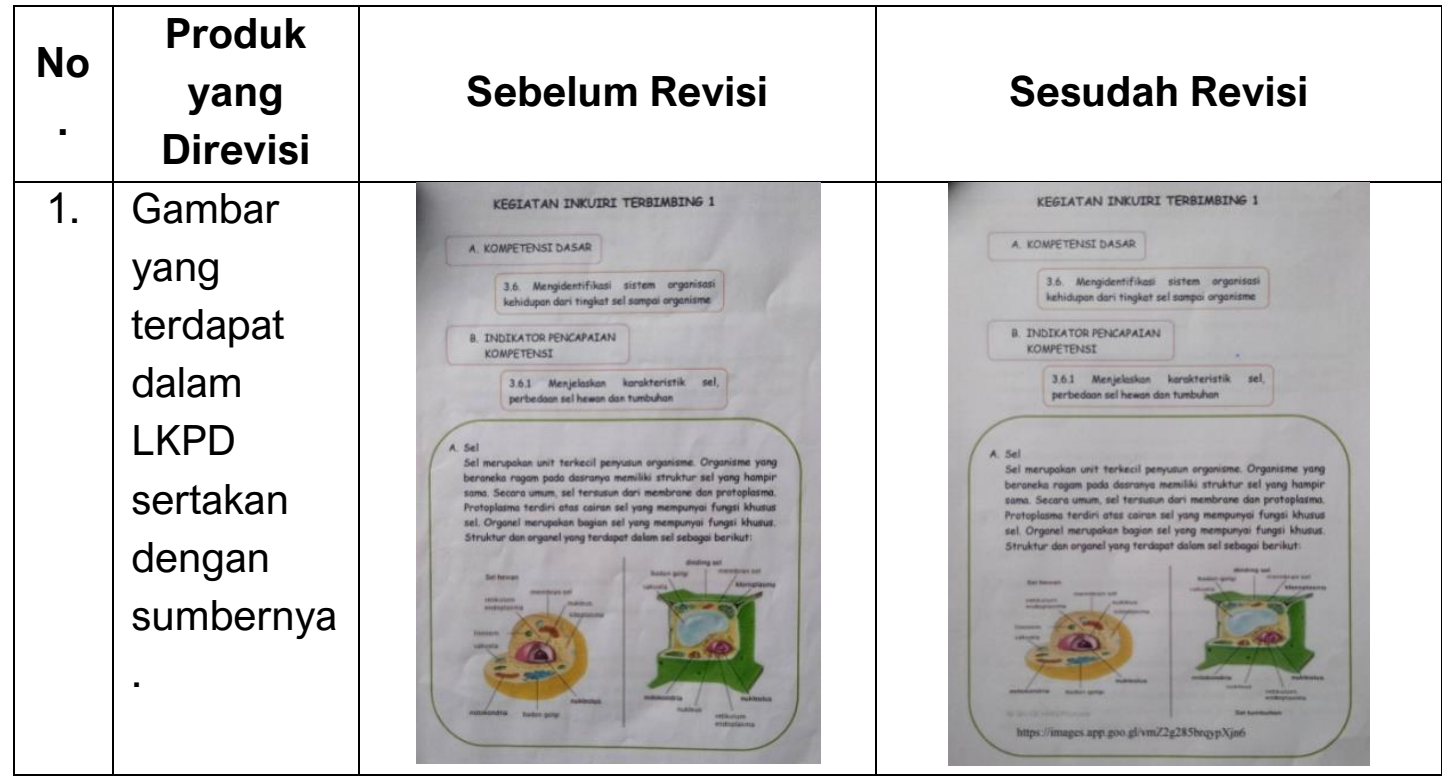

Validasi bahasa

Validator bahasa melakukan validasi terhadap tata bahasa dan tulisan pada media pembelajaran

dikembangkan jumlah yang dengan

10 pernyataan. 
Kesimpulan dari validasi bahasa sangat valid.

3. Pengembangan (development)

a) Produk yang dihasilkan

Dalam penelitian pengembangan ini adalah media pembelajaran berupa LKPD. Pengembangan media pembelajaran berbasis inkuiri terbimbing yaitu dimana peserta didik akan diberikan sebuah soal berbentuk pernyataan terkait dengan pembelajaran biologi materi sistem organisasi kehidupan dan jawaban yang akan diberikan peserta didik dalam bentuk pertanyaan yang muncul dalam LKPD.

b) Validasi Ahli

Pada tahap ini dilakukan validasi. Produk yang telah selesai dibuat akan di validasi oleh ahli media, ahli materi, dan ahli bahasa. Para ahli diminta melakukan validasi pembelajaran yang dikembangkan berupa LKPD berbasis inkuiri termbimbing.

4. Implementasi (Implementation)

a) Uji coba lapangan

Uji coba produk merupakan bagian yang sangat penting pada penelitian penerapan, yang dilakukan setelah

\section{Analisis Data}

1. Data analisis validitas

LKPD inkuiri terbimbing terlebih dahulu divalidasi oleh para ahli yang terdiri dari ahli materi, ahli media dan ahli bahasa. Setiap ahli rancangan produk selesai. Uji coba produk bertujuan untuk melihat sejauh mana produk yang dibuat telah layak digunakan atau belum. Produk yang baik jika memenuhi kriteria yaitu kriteria valid, dan angket respon guru dan peserta didik. Pada tahap ini produk diuji cobakan dikelas VII SMP Negeri 1 Kewapante.

5. Evaluasi

Tahap terakhir dalam ADDIE adalah tahap evaluasi. Tahap evaluasi merupakan tahap untuk mengukur ketercapaian pengembangan LKPD. Peneliti menilai kelayakan LKPD yang dikembangkan berdasarkan hasil validasi LKPD dan respon peserta didik dan guru setelah menggunakan LKPD berbasis inkuiri terbimbing. Kelayakan LKPD yang pertama diukur dari hasil validasi meliputi validasi ahli materi, validasi ahli media, dan validasi ahli bahasa. Hasil keseluruhan validasi LKPD menunjukkan rata-rata dalam kategori sangat valid digunakan. Kelayakan LKPD selanjutnya diukur dengan respon peserta didik dan guru. Setelah menggunakan LKPD, peserta didik menunjukkan kategori sangat valid.

bertugas sebagai validator dan memberikan penilain terhadap LKPD inkuiri terbimbing yang telah dikembangkan. Ahli materi bertugas menilai aspek materi. 
Nilai yang di peroleh dari aspek materi $84 \%$, dimana nilai tersebut berada pada kategori sangat valid. Ahli media bertugas menilai pada aspek media. Nilai yang di peroleh dari aspek media adalah 90\%, dimana nilai tersebut berada pada kategori sangat valid. Ahli bahasa bertugas pada aspek bahasa. Dimana nilai yang di peroleh dari aspek bahasa adalah 90\%, dan nilai tersebut berada pada kategori sangat valid.

Table 4. Data Hasil Validasi Oleh Validator

\begin{tabular}{rlll}
\hline No & Validator & Data hasil validasi (\%) & Tingkat validitas \\
1. & Materi & $80 \%$ & Sangat valid \\
2. & Media & $90 \%$ & Sangat valid \\
3. & Bahasa & $90 \%$ & Sangat valid \\
\hline
\end{tabular}

Berdasarkan tabel dan
disimpulkan bahwa penilaian yang
diberikan oleh para ahli dari ahli
materi, ahli media dan ahli bahasa
produk yang dikembangkan
memenuhi kriteria "sangat valid".
Produk LKPD yang dikembangkan
yang memiliki nilai yang sangat
valid dapat dilanjutkan untuk
diujikan pada kelas percobaan

(Pada et al. 2021; Ra'o et al. 2021). Media menjadi poin penting dalam pengembangan LKPD karena dapat emmepngaruhi minat peserta didik dalam pembelajaran (Bare et al. 2021).

2. Hasil Analisis Data Kelayakan

a. Hasil analisis data uji coba lapangan oleh guru dan peserta didik.

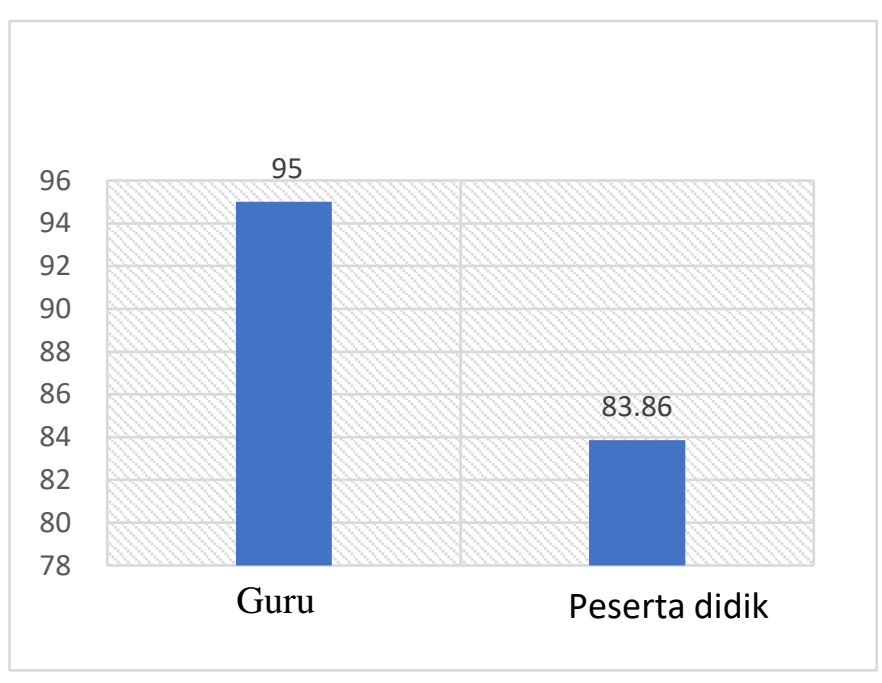

Gambar 13. Penilaian LKPD uji coba lapangan

Uji kelayakan LKPD pada uji coba lapangan yaitu 1 orang guru biologi dan 23 orang peserta didik kelas VII SMP Negeri $1 \quad$ Kewapante. Berdasarkan analisis angket 
kelayakan oleh guru terhadap LKPD diketahui bahwa LKPD dikategorikan layak dengan nilai 95 dengan kategori sangat layak dan hasil uji kelayakan oleh peserta didik dikategorikan sangat layak dengan nilai 83,86. Uji kelayakan LKPD mendapatkan respon baik dari guru dan peserta didik. Hasil penelitian yang dilakukan menunjukan LKPD yang dikembangkan dapat dikatakan layak digunakan. LKPD yang diekmbangakn dengan kategori layak dapat diimplementasikan dalam pembelajaran di kelas (Ade et al. 2021; Elci et al. 2021).

\section{Kesimpulan}

Berdasarkan analisis $r$ hasil
pengeolahan dan penelitian
dilakukang dan
kesimpulan

pembelajaran LKPD berbasis inkuiri terbimbing dinyatakan valid dan layak dikelas VIII.

\section{Daftar Pustaka}

Ade, Maria Yuniati Nona, Yohanes Bare, and Oktavius Yoseph Tuta Mago. 2021. "Pengembangan Media Pembelajaran Teka-Teki Silang (TTS) Pada Materi Sistem Gerak Untuk Kelas XI SMA." JURNAL PENDIDIKAN MIPA 11(2):63-75. doi: 10.37630/jpm.v11i2.485.

Bare, Yohanes, Sukarman Hadi Jaya Putra, Yohanes Nong Bunga, Oktavius Yoseph Tuta Mago, Mansur S, and Yohanes Tematan Boli. 2021. "Implementasi Biology Club I Di SMA Karitas Watuneso, Kecamatan Lio Timur, Kabupaten Ende." Jurnal ABDINUS: Jurnal Pengabdian Nusantara 4(2):321-28. doi: https://doi.org/10.29407/ja.v4i2.15286.

Bare, Yohanes, and Dewi Ratih Tirto Sari. 2021. "Pengembangan Lembar Kerja Mahasiswa (LKM) Berbasis Inkuiri Pada Materi Interaksi Molekuler." BioEdUIN 11(1):8. doi: https://doi.org/10.15575/bioeduin.v11i1.12077.

Dawa, Ratna Susana, Yohanes Nong Bunga, and Yohanes Bare. 2021. "Pengembangan LKPD Berbasis Inkuiri Terbimbing Pada Materi Sistem Pencernaan di SMAS Katolik St. Gabriel." Jurnal IImiah Wahana Pendidikan 7(8). doi: 10.5281/ZENODO.5781429.

Elci, Theresia Nona, Yohanes Bare, and Oktavius Yoseph Tuta Mago. 2021. "Pengembangan Media Pembelajaran Biologi Berbasis Android Menggunakan Model Pembelajaran Problem Based Learning Pada Materi Sistem Ekskresi Di Kelas VIII SMP." JURNAL PENDIDIKAN MIPA 11(2):54-62. doi: 10.37630/jpm.v11i2.484. 
Fara, Umi. 2019. "PENGEMBANGAN LKPD BERBASIS INKUIRI TERBIMBING UNTUK MENINGKATKAN KEMAMPUAN KOMUNIKASI MATEMATIS DAN SELF EFFICACY SISWA." Universitas Lampung, Bandar lampung.

Kari, Magdalena Letek, Yohanes Bare, and Oktavius Yoseph Tuta Mago. 2022. "Persepsi Mahasiswa Terhadap Pembelajaran Berbasis Blended Learning dengan Memanfaatkan Aplikasi Microsoft Teams." Qalam: Jurnal IImu Kependidikan 10(2):10. doi: https://doi.org/10.33506/jq.v10i2.1418.

Kemendikbud. 2013. "MENTERI PENDIDIKAN DAN KEBUDAYAAN REPUBLIK INDONESIA,." 16.

Khasanah, Uswatun. 2020. "PENGEMBANGAN LEMBAR KERJA PESERTA DIDIK (LKPD)BERBASIS INKUIRI TERBIMBING PADA MATERI OPERASI HITUNG BILANGANUNTUK PESERTA DIDIK KELAS IV MI." UIN Raden Intan Lampung.

Kurniawan, A. D. 2013. "METODE INKUIRI TERBIMBING DALAM PEMBUATAN MEDIA PEMBELAJARAN BIOLOGI UNTUK MENINGKATKAN PEMAHAMAN KONSEP DAN KREATIVITAS SISWA SMP." Jurnal Pendidikan IPA Indonesia.

Lia. 2019. "PENGEMBANGAN LEMBAR KERJA PESERTA DIDIK (LKPD) BERBASIS INKUIRI TERBIMBING MATERI KOLOID PADA KELAS XI SMA." Universitas Sriwijaya, Indralaya.

Marti, Marti, Syamswisna Syamswisna, and Ruqiah Ganda Putri Panjaitan. 2016. "EFEKTIVITAS PEMBELAJARAN KOOPERATIF TIPE NHT (NUMBERED HEADS TOGETHER) DENGAN MEDIA VISUAL TERHADAP HASIL BELAJAR SISWA PADAMATERI ORGANISASI KEHIDUPAN DI KELAS VII SMP REHOBOTH." Jurnal Pendidikan Matematika dan IPA 5(2). doi: 10.26418/jpmipa.v5i2.13336.

Maulidar. 2019. "PENGEMBANGAN LKPD BERBASIS PBL (PROBLEM BASED LEARNING) PADA MATERI LAJU REAKSI DI SMA NEGERI 1 SIMPANG KIRI." UIN Ar-Raniry, Banda Aceh.

Ndia, Fransiskus Xaverius, Oktavius Yoseph Tuta Mago, and Yohanes Bare. 2021. "Pengembangan Lembar Kerja Peserta Didik (LKPD) Koopertif Tipe Jigsaw Materi Klasifikasi Makhluk Hidup Kelas VII SMP." Quagga: Jurnal Pendidikan Dan Biologi 13(2):24-30. doi: 10.25134/quagga.v13i2.4011.

Pada, Krisna, Yohanes Bare, and Sukarman Hadi Jaya Putra. 2021. "Pengembangan Lembar Kerja Peserta Didik (LKPD) Biologi Berbasis Pendekatan Scientific Materi Sistem Ekskresi Pada Manusia Kelas VIII SMP Negeri 2 Maumere." Jurnal Ilmiah Wahana Pendidikan 8(7):337-49. doi: 10.5281/ZENODO.5769603.

Ra'o, Paula Yunita Seku, Yohanes Bare, and Sukarman HAdi Jaya Putra. 2021. "Pengembangan Media Teka-Teki Silang Biologi Berbasis Android Materi 
Sistem Gerak untuk Meningkatkan Keterampilan Berpikir Kreatif Siswa." JURNAL PENDIDIKAN MIPA 11(2):158-67. doi: 10.37630/jpm.v11i2.508.

S, Mansur, and Yohanes Bare. 2019. "Meningkatkan Hasil Belajar Siswa pada Konsep Perubahan dan Pelestarian Lingkungan Hidup dengan Model Discovery Learning di SMAS Katolik ST Gabriel Maumere." BIOEDUSCIENCE: Jurnal Pendidikan Biologi dan Sains 3(2):84-89. doi: 10.29405/j.bes/3284893298.

Tangkas, Made I. 2012. "PENGARUH IMPLEMENTASI MODEL PEMBELAJARAN INKUIRI TERBIMBING TERHADAP KEMAMPUAN PEMAHAMAN KONSEP DAN KETERAMPILAN PROSES SAINS SISWA KELAS $X$ SMAN 3 AMLAPURA."

Triana, Neni. 2018. "PENGEMBANGAN LEMBAR KERJA PESERTA DIDIK BERBASIS INKUIRI PADA MATERI SIFAT KOLIGATIF LARUTAN DI SMA NEGERI 1 MESJID RAYA." UIN Ar-Raniry, Banda Aceh.

Ule, Kristina Novita, Yohanes Nong Bunga, and Yohanes Bare. 2021. "Pengembangan Modul Pembelajaran Biologi Berbasis Jelajah Alam Sekitar (JAS) Materi Ekosistem Taman Nasional Kelimutu (TNK) SMA Kelas X." Diklabio: Jurnal Pendidikan dan Pembelajaran Biologi 5(2):10. doi: https://doi.org/10.33369/diklabio.5.2.147-156. 